JOURNAL OF NURSING PRACTICE AND EDUCATION

VOL. 01 NO. 02, JUNI 2021

DOI: $\underline{10.34305 / \mathrm{JNPE} . V 1 \mathrm{I} 2.277}$
Ciptaan disebarluaskan di bawah

Lisensi Creative Commons Atribusi-

NonKomersial-BerbagiSerupa 4.0

Internasional. (c) (1) (2) (2)

\title{
PERAN ORANG TUA DENGAN ASUPAN GIZI IBU NIFAS
}

\author{
Merissa Laora Heryanto, Fera Riswidautami Herwandar, Ayu Tresna Yanti Rohidin
}

STIKes Kuningan

merissaloara@gmail.com

\begin{abstract}
Abstrak
Kekurangan gizi pada masa nifas dapat mengakibatkan gangguan Kesehatan pada ibu dan bayinya. Hasil observasi peneliti di desa Sagarahiang yang merupakan wilayah UPTD Puskesmas Darma pada 10 ibu nifas yang tinggal bersama orang tuanya didapatkan 8 ibu nifas dilarang oleh orang tuanya makan ikan, telur dan daging dengan alasan percaya kepada mitos yang mengatakan rasa ASI akan menjadi bau. Tujuan penelitian ini untuk mengetahui hubungan antara peran orang tua dengan asupan gizi ibu nifas di Desa Sagarahiang dan Desa Karangsari Kecamatan Darma. Metode penelitian menggunakan rancangan cross sectional. Teknik pengambilan sampel menggunakan purposive sampling dengan jumlah sampel sebanyak 31 responden. Analisa data menggunakan uji Chi square. Hasil analisis bivariat terdapat hubungan antara peran orang tua dengan asupan gizi ibu nifas dengan nilai $\mathrm{p}=0,001$. Kesimpulan: terdapat hubungan antara peran orang tua dengan asupan gizi ibu nifas di Desa Sagarahiang dan Karangsari. Ibu nifas diharapkan meningkatkan pengetahuannya agar dapat memberikan asupan gizi yang baik untuk dirinya sendiri demi Kesehatan ibu nifas dan bayi yang disusuinya.
\end{abstract}

Kata kunci: Peran Orang Tua dan Asupan Gizi Ibu Nifas

\section{Pendahuluan}

Masa nifas sering disebut masa postpartum atau puerperium yang merupakan masa setelah pengeluaran plasenta dan berakhir pada saat alat-alat reproduksi kembali seperti keadaan sebelum kehamilan. Lamanya masa nifas biasanya selama kirakira 6 minggu atau 42 hari, akan tetapi secara 
JOURNAL OF NURSING PRACTICE AND EDUCATION

VOL. 01 NO. 02, JUNI 2021

DOI: $10.34305 /$ JNPE.V1I2.277

keseluruhan akan pulih dalam waktu 3 bulan (MaUse the "Insert Citation" button to add citations to this document.

rmi, 2017). Adapun kebutuhan dasar ibu nifas adalah cairan dan nutrisi, eliminasi, ambulasi, istirahat tidur, hubungan seksual, pemberian ASI, senam nifas dan keluarga berencana, semua kebutuhan dasar ini harus terpenuhi dengan cukup (Pitriani \& Andriyani, 2014).

Ibu nifas yang menjalani proses persalinan secara spontan atau normal tidak ada pantangan makanan, setelah proses persalinan selesai ibu boleh makan dan minum seperti biasanya, akan tetapi ibu nifas harus memperhatikan jumlah kalori dan proteinnya. Begitupun dengan masa Ketika ibu menyusui yang dianjurkan untuk lebih besar porsi jumlah kalori dan proteinnya dari pada ibu hamil, kecuali jika ibu tidak memberikan ASI kepada bayinya (Walyani \& Purwo Astuti, Th, 2017). Pada masa nifas, Kebutuhan gizi ibu membutuhkan nutrisi 500 kalori (5-6 kali) per-hari dengan porsi makan gizi seimbang, kemudian untuk vitamin dan mineral dibutuhkan minum minimal 8-12 gelas tiap hari dan pil
Ciptaan disebarluaskan di bawah Lisensi Creative Commons AtribusiNonKomersial-BerbagiSerupa 4.0 Internasional.

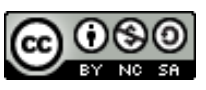

penambah darah (zat besi) diminum sehari 1 tablet untuk memenuhi gizi ibu nifas setidaknya sampai 40 hari setelah melahirkan (Arisman, 2014).

Makanan yang dikonsumsi ibu bermanfaat untuk menjaga daya tahan tubuh, mempercepat pengembalian alat-alat reproduksi seperti keadaan sebelum hamil, berguna untuk metabolisme dan aktivitas tubuh, dapat memperbanyak produksi ASI dan membantu penyembuhan luka-luka yang diakibatkan dari proses persalinan. Asupan makanan ibu nifas yang seimbang harus mempunyai kandungan sebagai sumber tenaga, pembangun dan pengatur (Rini \& Kumala, 2017). Sedangkan (Ambarwati, 2009) mengemukakan bahwa ada beberapa makanan yang sebaiknya tidak dikonsumsi oleh ibu nifas diantaranya makanan yang pedas, coklat, kopi, vitamin C yang berlebihan, makanan yang mengandung lemak jenuh, minuman alkohol dan merokok.

Mengukur status gizi ibu menyusui sama dengan menentukan status gizi usia 
JOURNAL OF NURSING PRACTICE AND EDUCATION

VOL. 01 No. 02, JUNI 2021

DOI: $\underline{10.34305 / \mathrm{JNPE} . V 1 \mathrm{I} 2.277}$

wanita subur yaitu dengan menggunakan indeks massa tubuh (IMT) dan LiLA. Dikatakan berat badan normal apabila IMT 18,5-25 dan dikatakan kurus apabila IMT 17,0-18,5. Cara mengukur IMT yaitu BB/TB2, sedangkan untuk LiLA di katakan KEK apabila LiLA < 23,5 cm dan normal jika $\geq 23,5 \mathrm{~cm}$ (Marmi, 2017). Adapun asupan gizi makanan ibu nifas menurut (Sulistyawati, 2009), mengkategorikan berdasarkan frekuensi konsumsi dalam satu bulan yaitu sering apabila $\geq 1 \mathrm{x} /$ hari dan 4-6x/minggu, jarang/tidak pernah apabila < 1-3 x/minggu dan tidak pernah.

Peran orang tua di keluarga dalam memenuhi asupan gizi ibu nifas mempunyai pengaruh yang kuat terhadap kesehatan ibu nifas terutama yang satu rumah dengan orang tuanya karena orang tua mempunyai
Ciptaan disebarluaskan di bawah

Lisensi Creative Commons Atribusi-

NonKomersial-BerbagiSerupa 4.0

Internasional.

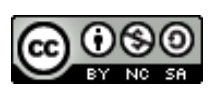

berbagai peran diantaranya sebagai pendidik, pendorong, panutan, teman, pengawas dan sebagai konselor. Peran orang tua sebagai pendidik dalam penyediaan kebutuhan nutrisi dan gizi ibu nifas diantaranya dengan cara menasehati, mendampingi, memberitahu makanan yang baik yaitu makanan yang bergizi seimbang dalam bentuk yang beraneka ragam sehingga tumbuh kesadaran pada ibu nifas yang dapat menimbulkan kondisi ibu cepat sehat dan bayi dapat tumbuh kembang dengan baik. Salah satu yang mempengaruhi peran orang tua dalam asupan gizi ibu nifas itu adalah budaya (Asih \& Pratiwi, 2010).

Gangguan kesehatan yang ibu nifas alami setelah melahirkan mengakibatkan orang tua akan melakukan perannya untuk melindungi anaknya dengan tujuan agar anaknya menjadi sehat dengan memberikan informasi sesuai pengalaman yang pernah orang tua alami (Ahmadi, 2014). Kebudayaan yang mengharuskan menghindari makanan tertentu pada masa nifas, mengakibatkan kekeliruan yang terjadi di masyarakat dengan adanya pantangan makan, contohnya tidak boleh 
JOURNAL OF NURSING PRACTICE AND EDUCATION

VOL. 01 NO. 02, JUNI 2021

DOI: $10.34305 /$ JNPE.V1I2.277

makan daging, telur, dan ikan agar luka jahitannya cepat sembuh, kemudian tidak boleh mengkonsumsi buah-buahan selama menyusui karena dapat mengakibatkan diare pada bayi, tidak mengizinkan makan terlalu banyak agar ibu nifas tetap langsing (Candra, 2013).

Gizi kurang pada masa nifas mengakibatkan gangguan kesehatan pada ibu dan bayinya seperti bayi kekurangan imunitas, gangguan tumbuh kembang anak,bayi dapat dengan mudahnya terkena infeksi, kekurangan nutrisi penting dapat menyebabkan gangguan pada mata atautulang. Selanjutnya dampak pada ibu nifas diantaranya menurunnya produksi dan kualitas ASI, luka dari proses persalinan tidak cepat sembuh, proses pengembalian alat-alat reproduksi dapat terganggu, anemia (kurang darah) dan dapat terjadi infeksi (Milah, 2019).

Berdasarkan hasil penelitian Hartiningtiyaswati (2010), ada hubungan yang signifikan antara perilaku pantang makanan dengan lama penyembuhan luka perineum pada ibu nifas (Hartiningtiyaswati, 2010). Hal ini juga didukung penelitian
_Ciptaan disebarluaskan di bawah Lisensi Creative Commons AtribusiNonKomersial-BerbagiSerupa 4.0 Internasional.

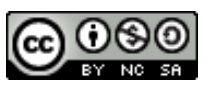

Latifah (2019), menyatakan bahwa faktorfaktor yang mempengaruhi penyembuhan luka perineum pada ibu post partum diantaranya pemenuhan kebutuhan nutrisi dengan tidak pantang makanan, perilaku ibu dalam menjaga personal hygiene dan mau melakukan mobilisasi dini dengan baik sehingga proses penyembuhan luka bekas melahirkan seperti luka jahitan perineum akan sembuh lebih cepat dan baik (Latifah, 2019).

Hasil observasi peneliti di desa Sagarahiang yang merupakan wilayah UPTD Puskesmas Darma pada 10 ibu nifas yang tinggal bersama orang tuanya didapatkan 8 ibu nifas dilarang oleh orang tuanya makan ikan, telur dan daging dengan alasan percaya kepada mitos yang mengatakan rasa ASI akan menjadi bau amis atau anyir dan supaya jahitan perineum cepat sembuh. Berdasarkan latar belakang diatas, peneliti tertarik melakukan penelitian mengenai hubungan antara peran orang tua dengan asupan gizi ibu nifas di Desa Sagarahiang dan Karangsari Kecamatan Darma Kabupaten Kuningan. 
menggunakan kuesioner. Analisis bivariat dengan Uji Chi square. Penelitian ini sudah lulus kaji etik dengan nomor kaji etik NO.33/EP/STIKKU/2020 dan seluruh responden sudah menyerahkan inform consent yang sudah disetujui dan ditandatangani,

\section{Hasil Penelitian}

\section{Hubungan antara Peran Orang Tua dengan Asupan Gizi Ibu Nifas di Desa Sagarahiang dan Karangsari Kecamatan Darma Kabupaten Kuningan}

Tabel 1 Distribusi Frekuensi Responden

\begin{tabular}{lcc}
\hline \multicolumn{1}{c}{ Variabel } & Frekuensi (n) & Persentase (\%) \\
\hline Peran Orang Tua & 18 & 58,1 \\
Baik & 9 & 29 \\
Cukup & 4 & 12,9 \\
Kurang & & \\
Asupan Gizi Ibu Nifas & 25 & 80,6 \\
Baik & 6 & 19,4 \\
Tidak Baik & & \\
\hline
\end{tabular}

Berdasarkan tabel 1 dapat diketahui bahwa dari 31 responden, didapatkan hasil sebagian besar peran orang tua dalam kategori baik yaitu sebanyak 18 responden $(58,1 \%)$ dan sebagian besar asupan gizi ibu nifas baik yaitu sebanyak 25 responden $(80,6 \%)$. 
Tabel 2 Hubungan antara Peran Orang Tua dengan Asupan Gizi Ibu Nifas di Desa Sagarahiang dan Karangsari Kecamatan Darma Kabupaten Kuningan

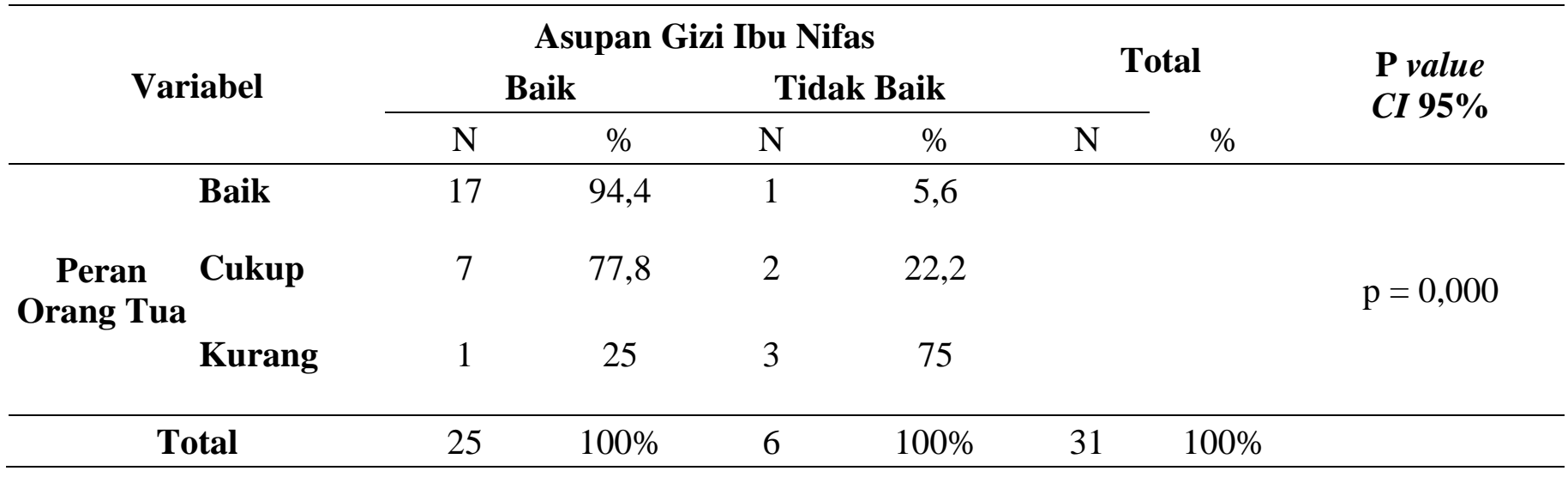

Berdasarkan tabel 2 dapat diketahui bahwa dari 31 responden didapatkan sebagian besar peran orang tua termasuk kategori baik dengan asupan gizi ibu nifas baik sebanyak 17 orang $(94,4 \%)$. Hasil analisis didapatkan didapatkan nilai nilai $P=0,001$ dengan tingkat signifikan $\propto=0,05$ artinya terdapat hubungan antara peran orang tua dengan asupan gizi ibu nifas di Desa Sagarahiang dan Karangsari Kecamatan Darma Kabupaten Kuningan. 
JOURNAL OF NURSING PRACTICE AND EDUCATION

VOL. 01 NO. 02, JUNI 2021

DOI: $\underline{10.34305 / J N P E . V 112.277}$

\section{Pembahasan}

Hasil analisis peran orang tua yang masuk dalam kategori baik didapatkan asupan gizi baik lebih banyak dibandingkan ibu yang peran orang tua masuk dalam kategori baik asupan gizi tidak baik, sedangkan peran orang tua dalam kategori cukup didapatkan lebih banyak asupan gizi ibu nifas yang baik dibandingkan yang tidak baik, dan peran orang tua yang masuk dalam kategori kurang asupan gizi ibu nifas yang tidak baik lebih banyak dibandingkan dengan asupan gizi yang baik. Berdasarkan hasil uji statistik menggunakan didapatkan nilai $P$ yaitu 0,001 dengan tingkat signifikan $\propto=0,05$ maka dapat disimpulkan terdapat hubungan antara antara peran orang tua dengan asupan gizi ibu nifas di Desa Sagarahiang dan Karangsari Kecamatan Darma Kabupaten Kuningan. Hal ini sejalan dengan penelitian dari Widowati (2016) menyatakan bahwa ibu mertua atau orang tua kandung mempengaruhi dalam memberikan anjuran atau larangan makanan yang akan dikonsumsi oleh ibu nifas sehingga suami mengikuti keputusan istri dan mendukung apa yang dianjurkan oleh ibu mertua atau ibu kandung sendiri (Widowati et al., 2016).
Ciptaan disebarluaskan di bawah Lisensi Creative Commons Atribusi-

$\underline{\text { NonKomersial-BerbagiSerupa } 4.0}$

Internasional.

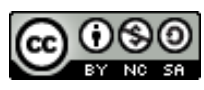

Berdasarkan hasil penelitian pada responden yang masuk dalam kategori peran orang tua baik didapatkan asupan gizinya baik, peneliti berasumsi hal ini disebabkan oleh adanya peran orang tua yang memberikan dukungan penuh terhadap anaknya sehingga pada saat ibu sedang susah atau mengalami kesulitan dalam mengurus rumah tangga karena adanya luka jahitan, orang tua tidak segan segan membantunya dengan penuh kasih sayang. Peran tersebut diantaranya membantu ibu menyediakan dan memberikan makan yang mengandung gizi seimbang, memberitahu ibu tentang ASI eksklusif dan mendengarkan keluhan ibu. Adanya dukungan tersebut membuat ibu merasa nyaman karena adanya perhatian sehingga kebutuhan gizi ibu dapat dipenuhi dengan baik. Hal ini sesuai dengan pendapat Kaplan (2013) yang mengatakan bahwa individu yang sangat membutuhkan dukungan selalu ingin mendapatkan perhatian dalam setiap keputusannya dalam menggapai suatu tujuan (Kaplan, 2013). Adanya pendapat tersebut dengan adanya perhatian yang penuh dari orang tua ataupun suami sehingga dapat mencegah terjadinya postpartum blues atau depresi pada ibu nifas dan dapat memunculkan 
JOURNAL OF NURSING PRACTICE AND EDUCATION

VOL. 01 NO. 02, JUNI 2021

DOI: $\underline{10.34305 / \mathrm{JNPE} . V 1 \mathrm{I} 2.277}$

niat untuk memakan makanan yang bergizi demi menjaga Kesehatan ibu dan bayinya. Hal ini juga didukung oleh penelitian Fairuz (2014) yang menyatakan bahwa ada hubungan antara depresi postpartum dengan dukungan suami, artinya bila dukungan dari pihak suami atau orang tua kurang baik maka ibu nifas berpotensi untuk terjadinya depresi (Fairus \& Widiyanti, 2014).

Berdasarkan hasil kuesioner banyak responden menjawab setuju dan sangat setuju pada soal poin 5 tentang orang tua ibu memberitahu ibu bahwa dulu ibu masih bayi sampai berumur 6 bulan hanya diberi ASI dan tidak pernah sakit-sakitan, sehingga ibu tanamkan pada anaknya sekarang untuk memberikan ASI secara eksklusif. Kondisi tersebut diartikan bahwa sebagian besar orang tua sudah memahami tentang pentingnya ASI eksklusif, maka orang tua sudah berperan sebagai pendidik bagi anaknya. Hal ini disebabkan oleh pengetahuan yang ibu dapat. Berdasarkan dari pengalaman masa lalunya. Hal ini juga didukung oleh hasil penelitian dari Anggraeni (2020) dan Kurniawati (2020) yang menyatakan bahwa ada hubungan dukungan keluarga dengan pemberian ASI eksklusif yang
Ciptaan disebarluaskan di bawah Lisensi Creative Commons Atribusi-

NonKomersial-BerbagiSerupa 4.0 Internasional.

artinya bahwa dukungan keluarga tersebut bisa dari suami dan dari orang tua termasuk ibu mertua (Anggraeni et al., 2020; Kurniawati et al., 2020). Hal ini sejalan dengan Kartono (2016) yang menyatakan bahwa keyakinan setiap manusia terhadap adanya dukungan terbentuk oleh variabel intelektual yang terdiri dari pengetahuan, latar belakang pendidikan dan pengalaman masa lalu (Kartono, 2016).

Adapun pada peran orang tua yang masuk dalam kategori baik tetapi kebutuhan gizinya tidak baik, peneliti menyimpulkan hal ini disebabkan oleh adanya kesibukan yang ibu miliki dalam mengurus rumah tangga. Berdasarkan hasil penelitian pada ibu yang mempunyai peran orang tua yang baik tetapi kebutuhan gizinya tidak baik didapatkan ibu sebagai pekerja dan mempunyai anak antara 34. Kondisi tersebut menimbulkan kelelahan pada ibu, meskipun ibu sudah melahirkan, tetapi ibu harus segera melakukan tugas sebagai ibu bagi keluarganya yang mengakibatkan ibu tidak terlalu memikirkan bagaimana pola makan yang baik, yang penting ibu merasa kenyang padahal pada kenyataannya harus mempunyai pola istirahat yang cukup dan memenuhi nutrisinya dengan gizi seimbang. Hal ini didukung oleh 
JOURNAL OF NURSING PRACTICE AND EDUCATION

VOL. 01 NO. 02, JUNI 2021

DOI: $10.34305 /$ JNPE.V1I2.277

penelitian dari Puspitaningsih (2017) bahwa faktor yang mempengaruhi asupan gizi ibu nifas diantaranya adalah kegiatan di rumah dan pekerjaan ibu, artinya jika ibu terlalu banyak beraktifitas dan menimbulkan kelelahan maka berpotensi untuk terjadinya asupan gizi ibu nifas yang kurang baik (Puspitaningsih, 2017). Hal ini sejalan dengan pendapat Varney (2011:127), menyatakan bahwa aktivitas yang berlebihan pada masa nifas seperti mengurus urusan rumah tangga dan mencari nafkah dengan pekerjaan yang berat dapat membahayakan kesehatan ibu nifas (Varney, 2011). Ibu nifas yang kelelahan juga akan mempengaruhi produksi ASInya seperti yang dinyatakan dalam penelitian Saraung (2017) bahwa kelelahan merupakan salah satu penyebab kurangnya produksi ASI, maka dari itu perlu adanya pengertian dari anggota keluarga dan dukungan keluarga agar membagi tugas rumah tangga untuk menghindari kelelahan pada ibu nifas (Saraung et al., 2017).

Berdasarkan hasil penelitian pada ibu yang masuk dalam kategori peran orang tua cukup dan asupan gizinya baik, peneliti berasumsi hal ini disebabkan oleh orang tua ibu sudah tua yang mengakibatkan peran orang tua
Ciptaan disebarluaskan di bawah Lisensi Creative Commons Atribusi$\underline{\text { NonKomersial-BerbagiSerupa } 4.0}$ Internasional.

kepada anaknya tidak sepenuhnya ibu berikan, ibu hanya bisa memberikan informasi atau memberikan anjuran pada anaknya tanpa dengan tindakan, seperti banyak makan sayur dan menganjurkan minum tablet tambah darah. Meskipun demikian, adanya peran dari orang tua, membuat ibu dapat mengerti dan mengetahui bagaimana asupan gizi yang baik pada masa nifas sehingga adanya peran orang tua membuat ibu berupaya untuk memenuhi kebutuhan gizinya sebaik mungkin agar kondisi ibu dan bayinya dalam keadaan sehat. Dalam hal ini ibu berperan sebagai konselor, sesuai dengan pendapat Maulani dalam Pratiwi (2010:3), yang menyatakan bahwa peran orang tua salah satunya sebagai konselor yakni dapat menentukan pertimbangan nilai positif dan negatif sehingga anak dapat mengambil keputusan yang terbaik (Asih \& Pratiwi, 2010).

Adapun pada peran orang tua yang dalam kategori cukup namun asupan gizi ibu nifas tidak baik, peneliti berasumsi hal ini disebabkan oleh adanya kondisi ekonomi ibu yang kurang. Berdasarkan hasil penelitian pada ibu yang peran orang tuanya cukup tetapi asupan gizinya tidak baik, didapatkan mempunyai anak 4 disamping itu ibu tidak bekerja, sehingga untuk 
JOURNAL OF NURSING PRACTICE AND EDUCATION

VOL. 01 NO. 02, JUNI 2021

DOI: $\underline{10.34305 / \mathrm{JNPE} . V 1 \mathrm{I} 2.277}$

mencukupi kebutuhan sehari-hari hanya mengandalkan dari suami yang mengakibatkan ibu hanya makan yang mengandung karbohidrat dan sumber serat saja tanpa memakan makanan yang mengandung banyak protein dan sebagainya. Hal ini sesuai dengan pendapat Ahmadi (2014), mengatakan salah satu faktor yang dapat mempengaruhi peran orang tua terhadap anaknya adalah sosial ekonomi (Ahmadi, 2014). Marmi (2017) menambahkan bahwa masalah yang berhubungan dengan gizi salah satunya adalah ekonomi. Keadaan ekonomi keluarga berpotensi mempengaruhi daya beli keluarga terhadap kebutuhan hidup primer maupun sekunder untuk keberlangsungan hidup. Keadaan ekonomi yang kurang mempengaruhi asupan nutrisi bagi keluarga (Marmi, 2017).

Selanjutnya peran orang tua yang masuk dalam kategori kurang namun asupan gizi ibu nifas baik, peneliti berasumsi disebabkan oleh pendidikan ibu yang tinggi yang mengakibatkan ibu mengerti asupan gizi yang baik untuk ibu nifas, sehingga meskipun peran orang tua kurang pada ibu ibu tetap mempunyai pola makan dengan asupan gizi yang baik untuk meningkatkan kesehatannya. Hal ini sesuai
Ciptaan disebarluaskan di bawah Lisensi Creative Commons Atribusi$\underline{\text { NonKomersial-BerbagiSerupa } 4.0}$ Internasional.

dengan pendapat Marmi (2017) yang menyatakan bahwa Pendidikan berperan untuk mengubah pola pikir masyarakat terhadap konsumsi gizi seimbang. Gizi seimbang dapat merubah kualitas hidup menjadi lebih baik serta dapat merubah kebiasaan buruk terhadap asupan nutrisi bagi tubuh. Pendidikan gizi juga diharapkan dapat merubah pengetahuan dan sikap yang berhubungan dengan status gizi (Marmi, 2017).

Adapun pada ibu yang peran keluarganya kurang dan asupan gizinya kurang, peneliti berasumsi hal ini disebabkan adanya informasi yang salah dari orang tua dimana adanya mitos berupa pantangan makan, seperti tidak boleh makan daging, telur dan ikan karena membuat rasa ASI jadi bau anyir atau amis juga membuat luka jahitan cepat sembuh, tidak memperbolehkan memakan makanan yang berkuah dan tidak boleh banyak minum air putih, tidak diperbolehkan mengkonsumsi buah-buahan selama menyusui karena dapat menyebabkan diare pada bayi, tidak boleh makan terlalu banyak supaya tetap langsing, dan dilarang makan terong karena bisa mengakibatkan tubuh ibu dan bayi menjadi gatal. Kondisi tersebut sudah membudaya di 
JOURNAL OF NURSING PRACTICE AND EDUCATION

VOL. 01 NO. 02, JUNI 2021

DOI: $\underline{10.34305 / J N P E . V 112.277}$

masyarakat, apabila ibu mempercayainya maka akan membawa dampak negatif, yaitu mengakibatkan asupan gizi pada ibu tidak baik. Hal ini sesuai dengan pendapat Marmi (2017) yang mengatakan bahwa kebudayaan merupakan ciri khas yang dimiliki oleh setiap daerah yang berbeda di Indonesia. Kebudayaan yang melekat pada masyarakat dapat mempengaruhi pola hidup dan sikap masyarakat tersebut. Kebudayaan dapat meningkatkan status gizi dan dapat menurunkan status gizi pada masyarakat sesuai ketentuan yang berlaku di masa tertentu siklus hidup manusia (Marmi, 2017).

Menurut Sulistyawati (2009), gizi atau nutrisi merupakan hal yang diperlukan oleh tubuh manusia untuk keperluan metabolisme tubuhnya. Gizi yang seimbang harus mengandung unsur-unsur sumber tenaga, pembangun dan pengatur (Sulistyawati, 2009). Meskipun demikian, menurut Ambarwati (2009) ada beberapa makanan yang lebih baik untuk dihindari oleh ibu nifas yaitu makanan yang pedas, kopi, coklat, makanan yang mengandung lemak jenuh, vitamin $\mathrm{C}$ yang berlebihan, merokok dan minuman beralkohol (Ambarwati, 2009).
Ciptaan disebarluaskan di bawah Lisensi Creative Commons AtribusiNonKomersial-BerbagiSerupa 4.0 Internasional.

\section{Kesimpulan}

Terdapat hubungan antara peran orang tua dengan asupan gizi ibu nifas di Desa Sagarahiang dan Karangsari Kecamatan Darma Kabupaten Kuningan dengan nilai $P=0,001$.

Hasil penelitian ini diharapkan ibu nifas lebih meningkatkan pengetahuannya khususnya dalam asupan gizi yang baik pada saat nifas sehingga terhindar dari mitos makanan pantangan yang dapat berdampak negatif bagi kesehatan ibu dan dapat mengatur menu makanan gizi seimbang tanpa terpengaruh oleh provokasi dari pola asuh orang tua yang tidak benar sehingga dapat memberikan informasi yang benar terhadap orang tua yang percaya pada mitos merugikan.

\section{Referensi}

Ahmadi. (2014). Psikologi Belajar. Rineka Cipta.

Ambarwati. (2009). Asuhan Kebidanan Nifas. Mitra Cendekia.

Anggraeni, I. E., Setyatama, I. P., \& Siswati. (2020). HUBUNGAN DUKUNGAN KELUARGA TERHADAP PEMBERIAN ASI EKSKLUSIF PADA IBU MENYUSUI. 11(2), 25-31. 
JOURNAL OF NURSING PRACTICE AND EDUCATION

VOL. 01 NO. 02, JUNI 2021

DOI: $10.34305 /$ JNPE.V1I2.277

Arisman, M. B. (2014). Buku Ajar Ilmu Gizi dalam Daur Kehidupan (2 ed.). Penerbit Buku Kedokteran EGC.

Asih, G. Y., \& Pratiwi, M. M. S. (2010). Perilaku Prososial Ditinjau Dari Empati Dan Kematangan Emosi. Jurnal Psikologi Universitas Muria Kudus, I(1), 33-42.

Candra, A. (2013, April). Mitos Keliru Seputar Makanan untuk Ibu Nifas. Lifestyle.Kompas.Com.

Fairus, M., \& Widiyanti, S. (2014). Hubungan dukungan suami dengan kejadian depresi postpartum pada ibu nifas. Jurnal Kesehatan, VII(1), 11-18.

Hartiningtiyaswati, S. (2010). Hubungan Perilaku Pantang Makanan dengan Lama Penyembuhan Luka Perineum pada Ibu Nifas Di Kecamatan Srengat Kabupaten Blitar.

Kaplan. (2013). Sinopsis psikiatrik. Binarupa Aksara.

Kartono, K. (2016). Pangantar Metodologi Riset Sosial. Alumni.

Kurniawati, R., Sari, W. I., \& Islamiah, D. (2020). HUBUNGAN ANTARA DUKUNGAN KELUARGA DENGAN PERILAKU IBU DALAM PEMBERIANASI EKSKLUSIF DI DESA TRENYANG WILAYAH KERJA PUSKESMAS SUMBERPUCUNG. 2(2), 155-160.
Ciptaan disebarluaskan di bawah Lisensi Creative Commons Atribusi-

NonKomersial-BerbagiSerupa 4.0 Internasional. (c) (i) (S) (2)

Latifah, A. (2019). Hubungan Perilaku Ibu Nifas Dengan Penyembuhan Luka Perineum. Kebidanan, 11(1), 17-22. https://doi.org/10.36456/embrio.vol11.no 1.a1845

Marmi. (2017). Asuhan Kebidanan pada Masa Nifas "Peurperium Care" (S. Riyadi (ed.); Cetakan ke). Pustaka Pelajar.

Milah, A. S. (2019). Nutrisi Ibu dan Anak (I. Rosidawati (ed.); Pertama). Edu Publisher.

Pitriani, R., \& Andriyani, R. (2014). Panduan Lengkap Asuhan Kebidanan Ibu Nifas Normal (ASKEB III) (I). Deepublish.

Puspitaningsih, D. (2017). Faktor Yang Mempengaruhi Pengetahuan Ibu Tentang Pemenuhan Kebutuhan Nutrisi Pada Ibu Nifas. Hospital Majapahit, 9(2), 48-56.

Rini, S., \& Kumala, F. (2017). Panduan Asuhan Nifas \& Evidence Based Practice (I). Deepublish.

Saraung, M. W., Rompas, S., \& Bataha, Y. B. (2017). ANALISIS FAKTOR-FAKTOR YANG BERHUBUNGAN DENGAN PRODUKSI ASI PADA IBU POSTPARTUM DI PUSKESMAS RANOTANA WERU. 5, 1-8.

Sulistyawati, A. (2009). Buku Ajar Asuhan Kebidanan Pada Ibu Nifas. Andi.

Varney, H. (2011). Buku Ajar Asuhan Kebidanan Edisi Empat. Kedokteran EGC.

Walyani, E. S., \& Purwoastuti, Th, E. (2017). 
JOURNAL OF NURSING PRACTICE AND EDUCATION

VOL. 01 NO. 02, JUNI 2021

DOI: $\underline{10.34305 / J N P E . V 112.277}$

Asuhan kebidanan Masa Nifas \& Menyusui (1st ed.). Pustakabarupress.

Widowati, I., Harnany, A. S., \& Amirudin, Z. (2016). Peran Keluarga Dalam Pengambilan Keputusan Ibu Nifas Untuk Melakukan Praktik Pantang Makanan Di Kota Pekalongan. Jurnal Litbang Kota
Ciptaan disebarluaskan di bawah Lisensi Creative Commons AtribusiNonKomersial-BerbagiSerupa 4.0 Internasional.

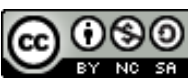

Pekalongan, 10, 30-41. 